\title{
Guevara GiL, Armando. Espejismos desarrollistas y autonomía comunal: el impacto de los proyectos de desarrollo en el lago Titicaca (1930-2006)
}

Alrededor del lado peruano del lago Titicaca, radican unas 150 comunidades campesinas que ejercen un alto grado de control autonómico sobre sus recursos — por ejemplo, pesquerías, totorales y aves acuáticas- . Lo hacen proyectando sus territorios comunales hacia el lago, con lo que crean espacios acuáticos exclusivos en los que imponen sus propias regulaciones. Esas prácticas y normas comunales contradicen los postulados del Derecho estatal sobre los recursos naturales, como un patrimonio de la nación administrado soberana y exclusivamente por el Estado. Así, las normas comunales se imponen aun a los pescadores o extractores de totora oficialmente autorizados. Para un proyecto nacional basado en la homogenización política y cultural, y no en la articulación de la diversidad, esos amplios márgenes de autonomía comunal constituyen, por supuesto, una anomalía que debe ser erradicada.

Por eso, y como parte de sus políticas integracionistas y asimilacionistas para solucionar el «problema indígena», el Estado peruano ha desplegado varios proyectos de desarrollo destinados a cambiar el paisaje social altiplánico e incorporar al lago Titicaca al dominio «nacional», para someterlo a una explotación «moderna, racional y eficiente». Esas iniciativas desarrollistas grafican el ímpetu modernizador estatal, la respuesta local, el fracaso de los proyectos que se imponen «desde arriba» y, sobre todo, el impacto que estos tienen en la configuración y reproducción de los derechos comunales, en especial en los espacios acuáticos comunales.

En el libro comentado, se describen la naturaleza y funciones de aquellos espacios. Luego se señala por qué el lago se transformó en un punto neurálgico de la imaginación desarrollista a partir de la década de 1930 y se presentan, a grandes rasgos, las características y consecuencias de los tres grandes proyectos que se idearon para transformarlo. Más allá del genuino esfuerzo estatal por incorporar a los pueblos y comunidades en sus planes y proyectos, el problema es que sus políticas han producido más conflictos que articulaciones entre el Estado y las comunidades campesinas. Ahora, esas disputas se producen no solo por el control de los «recursos naturales» del lago, sino también por los «recursos culturales» que la creciente actividad turística genera y explota. Las complejas y ambiguas relaciones entre la Reserva Nacional del Titicaca y la comunidad campesina-municipalidad-pueblo indígena Uros Chulluni, por ejemplo, ilustran los retos que el Derecho oficial enfrenta para procesar las demandas de reconocimiento y redistribución que las comunidades plantean. Esa tensión da pie para 
que el autor presente algunas ideas sobre el Derecho y el desarrollo en contextos interculturales.

La rigurosidad y calidad de este trabajo le han valido a su autor el Premio a la Investigación PUCP de 2008, razón por la cual hemos incluido su reseña en este número de la revista. 